\title{
Retraction
}

\section{Retracted: A Preliminary Qualitative Study of Two Common Acacia Species in Sudan}

\author{
Journal of Chemistry \\ Received 17 June 2014; Accepted 17 June 2014; Published 25 June 2014 \\ Copyright (C) 2014 Journal of Chemistry. This is an open access article distributed under the Creative Commons Attribution License, \\ which permits unrestricted use, distribution, and reproduction in any medium, provided the original work is properly cited.
}

The paper titled "A Preliminary Qualitative Study of Two Common Acacia Species in Sudan" [1], published in Journal of Chemistry, has been retracted as it is found to contain a substantial amount of material, without referencing, from the thesis titled "Tannins of Three Common Acacias of Sudan," Isam Eldin Hussein Elgailani, University of Khartoum, Sudan.

\section{References}

[1] A. A. Jacknoon, E. A. Elhefian, A. M. Mohammed, O. A. A. Hamdi, and A. H. Yahaya, "A preliminary qualitative study of two common Acacia species in Sudan," E-Journal of Chemistry, vol. 9, no. 2, pp. 851-856, 2012. 